\title{
Response of Fertilization with Goat Urine Fermentation Against the Growth of Leguminosa Indigofera (Indigofera zollingeriana) and Turi (Sesbania grandiflora) as animal feed ingredients in Samosir Regency
}

\author{
S Siagian, S Umar, N Ginting, T H Wahyuni, Hasnudi \\ Animal Production Program, Faculty of Agriculture, University of north sumatera, \\ Medan 20155 \\ E-mail: sondangsiagian19@gmail.com
}

\begin{abstract}
The need for animal feed in Pangururan District, Samosir Regency is very lacking, and livestock waste is also a problem in the community environment, so the utilization of EM4 goat's urine waste is expected to increase the growth of Indigofera (Indigofera zollingeriana) and Turi (Sesbania grandiflora) legumes in appropriate doses. . This research was conducted in Pangururan Subdistrict, Samosir Regency, North Sumatra from April to August 2018. The research design used in this research was factorial randomized block design (RBD) which was divided into 2 treatment groups and 3 replications. The first factor is the type of plant $(\mathrm{L}), \mathrm{L} 1=$ Indigofera zollingeriana and L2 $=$ Sesbania grandiflora and the second factor is the dose of fertilization $(\mathrm{P}), \mathrm{P} 0=$ without fertilization $($ Control), $\mathrm{P} 1=200 \mathrm{ml} /$ polybag, $\mathrm{P} 2=250 \mathrm{ml} /$ polybag, $\mathrm{P} 3=300 \mathrm{ml} /$ polybag, and $\mathrm{P} 4=350 \mathrm{ml} /$ polybag). Parameters observed were plant height, number of stalks, number of leaves, and stem diameter.

The results showed that respons of liquid organic fertilizer of goat urine fermented by EM4 with various doses of fertilization had a significant effect on the parameters of the study, namely plant height, number of stalks, number of leaves, and stem diameter. The conclusion of this study is that fertilization with a dose of $200 \mathrm{ml} /$ polybag gives optimal results in the growth of Indigofera (Indigofera zollingeriana) and Turi (Sesbania grandiflora) legumes.
\end{abstract}

\section{Introduction}

Forage is one of the ruminant's animal feed ingredients. General materials are something that can be learned by animals or livestock, can be partially or completely digested without the health assessment of the animals that eat them Tillman et al.1983 [1].

Forage legumes of indigofera zollingerianauan, other organic fertilizers. This forage is a legume plant with wood trunk and a long wave of productive period. This is in accordance with the research data from the Balai Besar Penelitian dan Pengembangan Kupang. 2013 [2]. which explains that this plant is very useful as animal feed because of its sufficient nutritional content for the growth and production of old livestock. In order for production to remain high, it must be fertilized with fertilizers that are easily absorbed by plants and safe for the environment. One alternative source of fertilizer that is easily absorbed and safe for the environment is organic fertilizer, which uses goat manure.

Turi leguminosa (Sesbania glandiflora) as animal feed, has very good potential for livestock both ruminants (such as cattle, goats, sheep, etc.) and non-ruminants. Turi is a class of legumes that are 
favored by livestock and their interest, favored by the community. Turi is resistant to repeated cuts. Its production can reach 20 tons of dry matter / ha / year Nista et a 2010 [3].

Organic fertilizers can overcome the negative consequences of fertilizer use inorganic with high doses continuously. There are two types of organic fertilizers derived from animal waste, namely solid organic fertilizer and liquid organic fertilizer Rizki, 2014: 2 [4].

Organic fertilizer from goat waste in the form of urine can be used as liquid organic fertilizer. Processing goat urine into liquid fertilizer can be done through a fermentation process. In the process of goat urine fermentation, use the help of decomposer or bioactivator bacteria such as EM4 (Effective Microorganism) which can be purchased at farm stores for approximately Rp 20,000 / liter. Nutrient content of goat urine is better than the nutrient content in the stool. The content of $\mathrm{N}, \mathrm{P}$ and $\mathrm{K}$ in goat urine is $1.35 \%, 0.05 \%$ and $2.10 \%$ respectively, while the nutrients in the stool are $0.75 \%, 0.50 \%$ and $0.45 \%$. When compared with other livestock urine, such as cow urine, sheep urine shows better quality, where the deficiency of $\mathrm{N}, \mathrm{P}$ and $\mathrm{K}$ in cow's urine is lower than sheep's urine, which is $1.0 \%$, $0.5 \%$ and $0.5 \%$ respectively. Santoso, 2013 [5].

Based on the description above, the researchers were interested in conducting a study on the growth of Indigofera Leguminosa (Indigofera Zollingeriana) and Turi (Sesbania grandiflora) Through Fertilizing Urine in Fermentation with EM4.

\section{Materials and Methods}

The study was conducted in the village of Parlondut, Pangururan sub-district, Samosir district, North Sumatra. This research lasted for 5 months which will be held from April to August 2018.

The ingredients used are goat urine, molasses / brown sugar, EM4, as ingredients for making organic fertilizers. Water for watering plants, polybags with a size of $5 \mathrm{~kg}$, soil and seeds of indigofera leguminosa (Indigofera zollingeriana) and seeds of thorn leguminous (Sesbania grandiflora). The tool used is jerry cans using 10 liters as a place of fermentation, bottles and small hoses to remove the fermented gas. Hoes, shovels, jerry cans, aqua bottles, plastic tarps, keyword-like nets, plastic ropes, cutting knives, machetes, data books, measuring tapes, rulers, sorong runes, stationery and calculators, loose for watering plants.

Factorial I: type of legume (L)

L1 = Legum Indigofera (Indigofera zollingeriana)

L2 = Legume Turi (Sesbania grandiflora)

Factor II: fertilizer dosage $(\mathrm{P})$

$\mathrm{P} 0=$ without fermented liquid fertilizer (control)

$\mathrm{P} 1$ = fermented liquid fertilizer with a dose of $200 \mathrm{ml} /$ polybag

$\mathrm{P} 2$ = fermented liquid fertilizer with a dose of $250 \mathrm{ml} /$ polybag

P3 = fermented liquid fertilizer with a dose of $300 \mathrm{ml} /$ polybag

$\mathrm{P} 4$ = fermented liquid fertilizer with a dose of $350 \mathrm{ml} /$ polybag

The data obtained will be analyzed, and if done significantly differently $(\mathrm{F}=0.5)$ then it is used further by using the Duncan test. The research parameters were plant height, number of stems, number of leaves, stem diameter

1. Plant height

Measurement of plant height using a measuring tape, from the base of the plant above the ground to the end of the plant canopy.

2. Number of Stalks

Plants were counted for the number of stems that grew in each treatment.

3. Number of Leaves

Plants were counted for the number of leaves growing in each treatment.

4. Stem Diameter 
The stem diameter is calculated using a caliper. Pengukran stem diameter is done on the surface of the soil by clamping the stem of the plant with a caliper. Then the measuring lever is shifted until it doesn't move anymore and you see the number on the sliding runway.

\section{Results and Discussion}

\subsection{Plant Height $(\mathrm{cm})$}

Table 1. Average plant height $(\mathrm{cm})$ indigofera legumes (Indigofera zollingeriana) and turi (Sesbania grandiflora) with different fertilizer doses ( $\mathrm{ml} /$ polybag)

\begin{tabular}{lllllll}
\hline Legumes & \multicolumn{5}{c}{ Treatment } & Average \\
\cline { 2 - 6 } & P0 & P1 & P2 & P3 & P4 & \\
\hline L1 & 10.66 & 26.04 & 21.29 & 17.77 & 14.96 & $18.14^{\mathrm{b}}$ \\
L2 & 17 & 32.39 & 24.13 & 26.80 & 24.50 & $24.96^{\mathrm{a}}$ \\
\hline Average & $13.83^{\mathrm{c}}$ & $29.21^{\mathrm{a}}$ & $22.7125^{\mathrm{b}}$ & $22.29^{\mathrm{b}}$ & $19.73^{\mathrm{b}}$ & \\
\hline
\end{tabular}

Description: Different superscriptions in the same row or column show the real number in the Duncan test $(\mathrm{p}<0.05)$

The results showed that administration of goat urine fermented EM4 significantly affected the height of indigofera legume plants (Indigofera zollingeriana) and turi (Sesbania grandiflora). The highest average value of plants was in treatment $\mathrm{P} 1$ with a dose of liquid organic fertilizer from the urine of fermented goats as much as $200 \mathrm{ml} /$ polybag of $29.71 \mathrm{~cm}$ while the lowest plants were found in treatment P0 (control) with an average of $13.83 \mathrm{~cm}$.

It can be seen from table 1 that turi leguminous (Sesbania grandiflora) has a plant growth that is faster than the growth of indigofera (Indigofera zollingeriana), where it can be seen the growth rate of plant height for turi (Sesbania grandiflora) is $24.96 \mathrm{~cm}$ and indigofera (Indigofera zollingeriana) $18.14 \mathrm{~cm}$.

The difference in plant height of each legume is caused by the provision of nutrients between treatments so that there is a high difference in each plant. Based on the results of the table it is known that treatment $\mathrm{P} 0$ produces plant height with an average of $13.83 \mathrm{~cm}$ which is significantly lower than the treatment (P1, P2, P3 and P4). This is due to the provision of fertilizers that automatically increase the growth of forages better than forages without fertilizer (P0). This is in accordance with the statement of Madjid et al. 2011 [6] which states that fertilizer is an organic or inorganic material which when added to the soil or to plants will improve the physical, chemical and biological properties of the soil and can remember plant growth. Peraturan Mentri Pertanian, 2009 [7] states that urine is a substance that is secreted through the kidneys in which there are food substances that have been digested, absorbed and even metabolized by body cells and then released through the kidneys and urinary tract. Urine has growth regulating substances and has repellents for pests or diseases.

3.2 number of stalks

Table 2. Average number of indigofera legumes (Indigofera zollingeriana) and turi (Sesbania grandiflora) with different fertilizer doses ( $\mathrm{ml} /$ polybag)

\begin{tabular}{lllllll}
\hline \multirow{2}{*}{ Legumes } & \multicolumn{5}{c}{ Treatment } & \multirow{2}{*}{ Average } \\
\cline { 2 - 6 } & P0 & P1 & P2 & P3 & P4 & \\
\hline L1 & 5.33 & 10.08 & 8.08 & 7.41 & 6.75 & $7.53^{\mathrm{b}}$ \\
L2 & 7.83 & 14.83 & 10.66 & 11.16 & 9.83 & $10.86^{\mathrm{a}}$ \\
\hline Average & $6.58^{\mathrm{c}}$ & $12.45^{\mathrm{a}}$ & $9.37^{\mathrm{b}}$ & $9.29^{\mathrm{b}}$ & $8.29^{\mathrm{b}}$ & \\
\hline
\end{tabular}

Description: Different superscriptions in the same row or column indicate a significant difference in the Duncan test $(\mathrm{p}<0.05)$ 
The results showed that administration of goat urine fermented EM4 significantly affected the number of indigofera leguminosa stalks (Indigofera zollingeriana) and turi (Sesbania grandiflora). The highest average number of stalks was in treatment P1 with a dose of liquid organic fertilizer from the urine of fermented goats as much as $200 \mathrm{ml} /$ polybag at 12.45 stalks while the average number of stalks was found in treatment P0 (control) with an average of 6.58 stalks.

It can be seen from table 2 that the thorn leguminosa (Sesbania grandiflora) has a higher average number of stalks compared to the average number of stalks of indigofera (Indigofera zollingeriana), which can be seen as 10.86 and indigofera (Indigofera zollingeriana) 7.53. Urine produced by livestock as a result of the body's metabolism has a very useful value, namely the levels of $\mathrm{N}$ and $\mathrm{K}$ are very high, besides the urine is easily absorbed by plants and contains plant growth hormones Sosrosoedirjo, 1981 [8], so urine fermented EM4 is used in legumes it results in good growth.

The difference in the average number of stalks for each legume is caused by the provision of nutrients between treatments so that there is a difference in the average number of stalks. Based on the results of the table it is known that treatment $\mathrm{P} 0$ produces an average number of stalks with an average of 6.58 which is significantly lower than the treatment (P1, P2, P3 and P4). It is suspected that the provision of liquid organic fertilizer (goat's urine) with sufficient fertilization into the soil is able to add nutrients to the soil which can be utilized by plants for growth, especially the number of leaf stalks. This is in accordance with the statement of ayub. 2004) [9] which states that, plants need nitrogen (N) for growth, especially in the vegetative phase, namely the growth of branches, leaves and stems. The main function of fertilizer is to provide or add nutrients needed by plants. Lingga and Marsono 2004 [10], stated that the main role of nitrogen $(\mathrm{N})$ contained in fertilizers given to plants is to stimulate overall growth, especially stems, branches and leaves. In addition nitrogen also plays an important role in the formation of leaf green which is very useful in photosynthesis. Another function is to form proteins, fats and various other organic compounds. So that liquid organic fertilizer (goat urine) is able to provide sufficient nutrients for plants. Hardjowigeno 2007 [11] which states that the main role of nitrogen for plants is to stimulate overall growth, especially the number of branches.

\subsection{Number of Leaves (strands)}

Table 3. Average number of leaves (strands) of indigofera legumes (indigofera zollingeriana) and turi (Sesbania grandiflora) with different fertilizer doses ( $\mathrm{ml} /$ polybag)

\begin{tabular}{lcccccc}
\hline \multirow{2}{*}{ Legumes } & \multicolumn{5}{c}{ Treatment } & \multirow{2}{*}{ Average } \\
\cline { 2 - 6 } & P0 & P1 & P2 & P3 & P4 & \\
\hline L1 & 37.33 & 102.33 & 76.583 & 61.08 & 46.75 & $64.81^{\mathrm{b}}$ \\
L2 & 134.33 & 368.75 & 230.25 & 249 & 203 & $237.06^{\mathrm{a}}$ \\
\hline Average & $85.833^{\mathrm{c}}$ & $235.54^{\mathrm{a}}$ & $153.41^{\mathrm{b}}$ & $155.04^{\mathrm{b}}$ & $124.87^{\mathrm{bc}}$ & \\
\hline
\end{tabular}

Description: Different superscriptions in the same row or column indicate a significant difference in the Duncan test $(\mathrm{p}<0.05)$

The results showed that administration of goat urine fermented EM4 significantly affected the height of indigofera legume plants (Indigofera zollingeriana) and turi (Sesbania grandiflora). The highest average value of plants is in treatment P1 with a dose of liquid organic fertilizer from the urine of fermented goats as much as $200 \mathrm{ml} /$ polybag at 235.54 strands while the lowest number of leaves is in treatment P0 (control) with an average of 85,833 strands.

It can be seen from table 3 that the thorn leguminous (Sesbania grandiflora) has a higher average number of leaves compared to the average number of indigofera leaves (Indigofera zollingeriana), which can be seen as the average number of leaves for turi (Sesbania grandiflora) of 237.06 strands and indigofera (Indigofera zollingeriana) amounting to 64.81 strands. This is in accordance with the statement of Nista. 2010 [12] stating that the characteristic of turi leaves is $30 \mathrm{~cm}$ long pinnate 
compound leaves with an even number of twins (twins) of around 20-50 child leaves. Oval or oval leaf shape. While Indigofera zollingeriana has elongated oval leaves with number of leaves per branch between 11-21 strands Sirait et al. 2009 [13]. So this also affects the average number of leaves higher in turi plants (Sesbania grandiflora) than indigofera (Indigofera zollingeriana).

The difference in the average number of leaves of each legume is caused by the provision of nutrients between treatments so that there is a difference in the average number of leaves. Based on the results of the table, it is known that treatment P0 produces an average number of leaves with an average of 85,833 strands which is significantly lower than the treatment (P1, P2, P3 and P4). Leaves on plants support plant growth because the leaves are one of the most important plant organs of plants that function as a place for photosynthesis. In accordance with the statement Syukron 2000: 14 [14] that the growth of plant height is in line with the development of the number of leaves. Leaves are the most important producer of photosynthate organs, increasing the number of leaves will give more photosynthate results.

Table 4. Stem Diameter (mm)

Table 4. Average number of stem diameter $(\mathrm{mm})$ indigofera legumes (Indigofera zollingeriana) and turi (Sesbania grandiflora) with different fertilizer doses ( $\mathrm{ml} /$ polybag)

\begin{tabular}{lllllll}
\hline \multirow{2}{*}{ Legumes } & \multicolumn{7}{c}{ Treatment } & Average \\
\cline { 2 - 6 } & P0 & P1 & P2 & P3 & P4 & \\
\hline L1 & 3.5 & 6.41 & 5.58 & 4.41 & 4 & $4.78^{\mathrm{b}}$ \\
L2 & 4.54 & 8.25 & 6.25 & 6.83 & 6 & $6.37^{\mathrm{a}}$ \\
\hline Average & $4.02^{\mathrm{d}}$ & $7.33^{\mathrm{a}}$ & $5.91^{\mathrm{b}}$ & $5.62^{\mathrm{bc}}$ & $5^{\mathrm{c}}$ & \\
\hline
\end{tabular}

Description: Different superscriptions in the same row or column indicate a significant difference in the Duncan test $(\mathrm{p}<0.05)$

The results showed that administration of goat urine fermented EM4 significantly affected the stem diameter of indigofera legumes (Indigofera zollingeriana) and turi (Sesbania grandiflora). The average diameter of stem diameter in treatment P1 with the dose of liquid organic fertilizer from urine of EM4 fermented goats was $200 \mathrm{ml} /$ polybag at $7.33 \mathrm{~mm}$ while the lowest average stem diameter was found in treatment P0 (control) with an average of $4.02 \mathrm{~mm}$.

It can be seen from table 4 that the thorn leguminosa (Sesbania grandiflora) has a higher stem diameter average compared to the indigofera stem diameter average (Indigofera zollingeriana), which can be seen from the stem diameter of thorn leguminous (Sesbania grandiflora) of $6.37 \mathrm{~mm}$ and indigofera (Indigofera zollingeriana) at $4.78 \mathrm{~mm}$. This is related to nutrients provided by liquid organic fertilizer from goat urine which can change the physical properties of the soil, especially in soil structure. Increased values of vegetative characters such as plant height and plant diameter are caused by the role of nitrogen elements. The main role of nitrogen for plants is to stimulate overall growth, especially the stems, branches, and leaves of Hardjowigeno 2007 [11]. Plants need nutrients that are suitable for their needs in the process of growth and development.

The parameters that have been examined in this study indicate that the growth of turi leguminous (Sesbania grandiflora) shows higher compared with indigofera growth (indigofera zollingeriana). Mulyoutami et, al 2017 [16], states that turi plants (Sesbania grandiflora) are considered the most beneficial for soil because besides their leaves can increase fertility if used as fertilizer or humus, it also has a type of deep and cold roots (capable of binding nitrogen). Land overgrown with turi has relatively high fertility. Although some of the roots can appear on the surface but the distribution is not too wide. Turi plants have rapid growth with small rods that are strong and not easily attacked by pets, and also have better nutrition for large livestock Kieft 2007 [17]. While fertilizing doses show that fertilizing with a dose of $200 \mathrm{ml} /$ polybag gives the results of more optimal research parameters, 
perhaps due to the dosage of $250 \mathrm{ml} /$ polybag, $300 \mathrm{ml} /$ polybag, and $350 \mathrm{ml} /$ polybag in plants which are excessive doses which can actually harm plants. Hardjowigeno. 2003 [11] states that giving excessive fertilizer will cause damage to the leaves. Plant roots have an important role as canopy.

\section{Conclusion}

The use of EM4 fermented goat urine as liquid organic fertilizer against the growth of Indigofera legumes (Indigofera zollingeriana) and Turi (Sesbania grandiflora) at a dose of $200 \mathrm{ml} /$ polybag shows plant growth, plant height, number of leaves, and more optimal stem diameter if compared with without the provision of liquid organic fertilizer, fermented goat urine. The use of EM4 fermented goat urine gave a more optimal response to Turi legumes (Sesbania grandiflora) compared to Indigofera Indigofera zollingeriana.

\section{References}

[1] Tillman, A. D., Hari H., Soedomo R., Soeharto P., dan Soekanto L. 1983. Ilmu Makan Ternak Dasar. Gadjah Mada University Prees. Fakulas Peternakan UGM.

[2] Balai Besar Penelitian dan Pengembangan Kupang. 2013. Indigofera Sp. Hijauan Bernutrisi Tinggi Untuk Ternak Kambing.

[3] Nista, D., Hesti, N., dan Sri, H. 2010. Keunggulan Turi sebagai pakan ternak. BPTU sembawa. Palembang

[4] Rizki, K. 2014. Pengaruh Pemberian Urin Sapi yang Difermentasi Terhadap Pertumbuhan dan Produksi Tanaman Sawi Hijau (Brassica rafa). Jom Faperta, 1(2): 1-9.

[5] Santoso, 2013. Produksi rumput gajah (Pennisetum purpureum) yang diberi pupuk N, P dan K dengan dosis 0, 50 dan 100\% pada devoliasi hari ke-45. Jurnal Sains Peternakan. 11 (1): 49-55.

[6] Madjid, M. D., Bachtiar, E. H., Fauzi H., Hamidah, H. 2011. Dasar Pupuk dan Pemupukan Kesuburan Tanah. USU Press. Medan.

[7] Peraturan Mentri Pertanian, 2009. Permentan No. 28/SR.130/5/2009. Persyaratan Teknis Minimal Pupuk Organik. Jakarta.

[8] Sosrosoedirdjo, R. S., B. Rivai \& S. S. Iskandar. 1981. Ilmu Memupuk 2. CV. Yasaguna, Jakarta.

[9] Ayub SP. 2004. Pupuk organik Cair. Agromedia Pustaka, Jakarta

[10] Lingga, P, \& Marsono, 2004, Petunjuk Penggunaan Pupuk, Penebar Swadaya, Jakarta.

[11] Hardjowigeno, H. S. 2007. Ilmu Tanah. Akademika Pressindo. Jakarta. 288 hal.

[12] Nista, D., Hesti, N., dan Sri, H. 2010. Keunggulan Turi sebagai pakan ternak. BPTU sembawa. Palembang

[13] Sirait J, Simanihuruk K, Hutasoit R. 2009. The potency of Indigofera sp. as goat feed: production, nutritive value and palatability. In: Proceeding of International Seminar on Forage Based Feed Resources. Bandung, 3-7 Agustus 2009. Taipei (Taiwan): Food and Fertilizer Technology Centre (FFTC) ASPAC,Livestock Research Centre-COA, ROC and IRIAP. p.4-7.

[14] Syukron. 2000. Pengaruh Perlakuan Pupuk Hijau Terhadap Bibit Setek Cabang Buah Tanaman Lada (Piper nigrum Linn.). Skripsi. Bogor: Fakultas Pertanian IPB.Suprihatin. 2010. Teknologi Fermentasi. Penerbit UNESA University Press. Jakarta.

[16] Elok Mulyoutami, Pratiknyo Purnomosidhi, Asep Suryadi, Iskak Nugky Ismawan, Nikolas Hanggawali, Gerhard Sabastian. 2017. Menanam di bukit gundul Pengetahuan masyarakat lokal dalam upayarestorasi lahan di Sumba Timur Suci Anggrayani dan James M Roshetko, bogor.

[17] Kieft JA. 2007. Farmers' Use of Sesbania grandiflora to Intensify Swidden Agriculture in North 